\title{
Long-Run Relationship between Fiscal Policy and Economic Growth in Asia: Evidence Using Pedroni's Cointegration Approach
}

\author{
HUSSIN ABDULLAH \\ College of Arts and Sciences \\ Universiti Utara Malaysia \\ MUZAFAR SHAH HABIBULLAH \\ AHMAD ZUBAIDI BAHARUMSHAH \\ TAN BOON HUI \\ Faculty of Economics and Management \\ Universiti Putra Malaysia
}

\begin{abstract}
This paper investigates the long-run relationship between fiscal policy and economic growth in Asia between 1982 and 2001 through the application of Pedroni's Cointegration approach. It examines two different channels through which fiscal policy can affect long-run economic growth in Asian countries. The first channel is when components and aggregate government expenditure affect the real per capita GDP, and the second channel is when the distortionary taxation, budget balance, and aggregate of other fiscal variables affect the real per capita GDP. There is a positive and statistically significant impact of health and education expenditure, aggregate of government expenditure, and aggregate of other fiscal variables on real per capita GDP. It was found that the defence expenditure, distortionary taxation, and budget balance are significantly and negatively related to real per capita GDP. The Pedroni Cointegration result establishes a long-run relationship between fiscal policy and economic growth.
\end{abstract}

Keywords: Economic growth; fiscal policy; government expenditures; panel cointegration test; FMOLS.

\begin{abstract}
ABSTRAK
Artikel ini mengkaji hubungan jangka panjang antara dasar fiskal dan pertumbuhan ekonomi di negara-negara Asia antara 1982-2001 melalui pendekatan ko-integrasi Pedroni. Ujian dilakukan melalui dua saluran yang berbeza yang mana dasar fiskal dapat memberi kesan jangka panjang ke atas pertumbuhan ekonomi. Saluran pertama ialah apabila komponen-komponen dan agregat perbelanjaan kerajaan memberi kesan ke atas Keluaran Dalam Negara Kasar (KDNK) per kapita benar dan saluran kedua ialah apabila pencukaian pengherotan (distortionary), imbangan belanjawan, dan agregat pemboleh ubah fiskal yang lain memberi kesan ke atas KDNK per kapita benar. Hasil kajian mendapati terdapat kesan yang signifikan dan positif bagi pemboleh ubah perbelanjaan kesihatan, perbelanjaan pendidikan dan agregat pemboleh ubah fiskal yang lain ke atas KDNK per kapita benar. Di samping itu perbelanjaan pertahanan, pencukaian pengherotan dan imbangan belanjawan mempunyai kesan yang signifikan dan negatif ke atas KDNK per kapita benar. Keseluruhannya dapat dikatakan bahawa keputusan ko-integrasi Pedroni ini menunjukkan wujudnya hubungan jangka panjang antara dasar fiskal dan pertumbuhan ekonomi di negara-negara Asian.
\end{abstract}




\section{INTRODUCTION}

Fiscal policies have a benign role for economic growth in the region, namely to provide a stable macro environment for investment. The changed environment of liquidity constraints on external borrowing and slowdown in output growth has led to new attention being directed toward the role and contribution of fiscal policies to reviving growth in the region (Gangopadhyay \& Chatterji, 2005). In the debate on economic policy, fiscal policies are predominantly viewed as an instrument to mitigate short-run fluctuations of output and employment (Benos, 2005). By a variation in government spending or/and taxation, fiscal policies aim at altering aggregate demand in order to move the economy closer to potential output. Fiscal policies were neither the cause of the crisis nor the critical determinant of economic growth. Nevertheless, their role in both the pre-crisis and post-crisis period in Asian countries has been seen as crucial, primarily in terms of its contribution to economic growth.

There are large differences among the Asian countries in their levels of living and other circumstances, as well as the policies that they have pursued. Larger government size is likely to be an obstacle to efficiency and economic growth because the taxes necessary to support government expenditures may distort incentives to work and to invest, absorb funds that otherwise would have been used by the private sector in profitable investment opportunities, generally reduce efficient resource allocation, and hence reduce the level of output. In addition, government operations are often carried out inefficiently, and the regulatory process imposes excessive burdens and costs on the economic system. Thus, countries with greater government expenditure as a proportion of output should experience lower economic growth. These arguments, together with the debt crises experienced, have led many countries to start a mass deregulation of market and privatisation of public enterprises (Mundle, 1999). Based on the above argument, and as we mentioned earlier, Keynesian economics predict government expenditure should lead to economic growth.
When looking at the growth performance in the Asian countries in recent decades, two observations are noteworthy. Firstly, growth has declined and become stagnant significantly since 1985. Secondly, government expenditure does not inhibit the full exploitation of growth potential of Asian economies. There is a broad consensus that these developments in fiscal policies contribute to the relatively weak growth performance in the Asian countries.

Fiscal positions vary significantly across countries and sub-regions. Significant fiscal deficit and accumulation of public debt are relatively new phenomena for most Asian economies. However, expenditure growth outpaced revenue growth in many Asian economies, leading to persistent budget deficits and high indebtedness. Weak fiscal positions have left little room for further fiscal expansion in most Asian economies when faced by economic slowdown. Moreover, measuring fiscal policy has always posed a difficult challenge.

The objective of this study was to examine the long-run relationship between components of fiscal policy and economic growth in Asian countries. Thus, this study aimed at filling a gap in research devoted solely to investigating the relationship between fiscal policy and economic growth using newly developed methods of panel cointegration by Pedroni (1999; 2004) and panel FMOLS estimator (Pedroni, 1996, 2000).

This paper is organised as follows. Section 2 contains a brief literature review. In section 3, the model is applied to the 13 Asian economies. Section 4 presents empirical results and the last section concludes.

\section{REVIEW OF RELATED LITERATURE}

The most recent empirical literature, mainly based on panel data regressions, showed that economic growth is significantly affected by fiscal policies, although there remained some lack of agreement on the sign of the effects. On the other hand, Caselli, Esquivel, and Lefort (1996) found robust positive contribution of the government expenditure ratio (net of defence and educational expenditure) to growth. In a similar 
way, Kneller, Bleancy, and Kneller (1999) found that public expenditure and taxation only affected growth if they were productive and distortionary, respectively; productive government expenditure was found to positively affect growth, whereas distortionary taxation was found to be harmful for growth. With this distinction they argued that both sides of the government budget should be considered in estimating the impact of fiscal policy on growth, as their financing offset the growthenhancing effects of productive expenditure. Gerson (1998) surveyed the theoretical and empirical literature on the effect of fiscal policy variables (government expenditure programmes and taxes) on economic growth. He concluded that educational attainment and public health status had significant and positive effects on per capita output growth; economies that were open to international trade grew faster than those that were closed, therefore fiscal policies that encouraged openness should encourage growth.

Zagler and Dürnecker (2003) surveyed the literature on fiscal policy and economic growth. They presented a unifying framework for the analysis of long-run growth implications of government expenditures and revenues. They found that the level of education expenditure and the growth rate of public infrastructure investment both exhibited a positive impact on the growth rate of the economy. Tanzi and Zee (1997) systematically examined the various ways that main fiscal instruments (tax policy, public expenditure policy, and budget policy) influenced economic growth through their impact on the determinants of growth.

There are researchers of international econometric studies in recent years had found a powerful negative effect of taxation on long-term GDP growth; Cashin (1995) studied 23 OECD countries over the 1971-1988 period. He found that $1 \%$ point of GDP increase in tax to GDP ratio lowers output per worker by $2 \%$. Engen and Skinner (1993) studied US modeling together with a sample of OECD countries. They found that $2.5 \%$ point increase in tax to GDP ratio reduces GDP growth by $0.2 \%$ to $0.3 \%$. Bleaney, Gemmell, and Kneller (2001) studied 17 OECD countries over the 1970-1994 period. They found that $1 \%$ point of GDP increase in distortionary tax revenue reduces GDP growth by $0.4 \%$ points. Fotster and Henrekson (2001) used sample of rich OECD/nonOECD countries over the 1970-1995 period. They found that $10 \%$ point increase in tax to GDP ratio reduces GDP growth by $1 \%$.

Studying the relationship between government expenditure and economic growth is becoming of crucial importance to divide government activities in several categories and methodologies, as was the case for Yasin (2003), who studied the relationship between government expenditure and economic growth. His study reexamined the effect of government spending on economic growth using panel data set from SubSaharan Africa. The results from both estimation techniques indicated that government spending, trade-openness, and private investment spending all had a positive and significant effect on economic growth. Biswas and Ram (1986) used data from 55 countries over the period 1960-1977 and found that defence expenditure has no significant effect on output growth. Abu-Bader and AbuQarm (2003) used multivariate cointegration and variance decomposition techniques to investigate the causal relationship between government expenditure and economic growth. Cross section growth regressions had been used to assess the relationship between defence expenditure and economic growth. They found that when considering overall government expenditure, there was bidirectional causality between government spending and economic growth, with a negative long-run relationship in the cases of Israel and Syria, and a unidirectional negative short-run causality from economic growth to government spending in the case of Egypt.

Landau (1986) examined the possibility that the impact of defence expenditure on output growth was nonlinear, with relatively low levels of defence expenditure enhancing output growth, but relatively low levels of defence expenditure inhibiting growth. He found that this was in fact the case, with a positive relationship between defence expenditure and output growth holding until defence expenditure reached about $4 \%$ of GDP and a negative relationship taking over at about $9 \%$ of GDP. For sub-samples restricted to Latin America and Africa, he found a significant, positive relationship between defence expenditure 
and the share of government education and health expenditure in GDP.

Hassan, Waheeduzzaman, and Rahman (2003) stated that there were essentially four arguments showing military expenditure retarding economic growth. Firstly, higher defence expenditures could crowd out both public and private investment that might be more growth-oriented and need-based than those of defence spending. This crowding out of essential investment might have an adverse impact on the long-run economic growth. Secondly, defense expenditure can cause balance of payment problems if hard-earned foreign exchanges were used to purchase arms and defence hardware. Thirdly, defence might inhibit growth by diverting resources from the export sector, which was often considered an engine of growth. Finally, the defence sector limited growth through inefficient bureaucracy and excess burdens created by taxes necessary to finance military spending. Since defence spending could cause both positive and negative effects, its final impact on growth would depend on the strength of the opposing forces.

Devarajan, Swaroop, and Zon (1996) investigated the relationship between the compositions of public expenditure and economic growth. Using a simple, analytical model, they derived conditions under which a change in the mix of public spending could lead to a higher steady-state growth rate for the economy. Based on the model, their empirical results suggested that expenditures that were normally considered productive could become unproductive if there was an excessive amount of them. Glomm and Ravikumar (1994) considered the relationship between government expenditure on infrastructure or education and economic growth, and the implication of their models' yield depended on how the expenditures were being conceived and how they looked at the effects of taxes that had to be raised to finance the expenditure.

Landau (1997) studied the impact of government expenditure for human capital - education and health - on economic growth, and the actual human capital created. The regression indicated that difference in government expenditure on human capital (as a share of GNP) had (a) no statistically significant impact on the rate of economic growth, and (b) limited impact on the actual levels of education and health achieved. He also conducted a study, for a cross section of developing countries, of the impact of government spending for human capital on economic growth and realised levels of education and health. With regard to the first question, while education and health contributed significantly to economic growth, higher government expenditure on education or health had no statistically significant positive impact on economic growth.

Barro and Sala-I-Martin (1995) found that government expenditure in education, health, and other services could contribute indirectly toward raising the marginal productivity of private sectors via their contribution on human capital accumulation. Hansson and Henrekson (1994) found a significant positive effect on growth from educational spending. Chen and Gupta (2006) examined the government expenditure in health and education, and other structural factors that may have an effect on economic growth. They applied the GMM estimation technique, which is the set explanatory variables included in the growth regression specification based on the endogenous growth theory that can all be considered to be important determinants of economic growth. The results showed that the coefficient on government expenditure in health and education is negative but is small in absolute value. Gbesemete and Gerdtham (1992) used a cross sectional sample of 30 African countries in 1984. They found that per capita GNP was the most significant factor in explaining per capita health care expenditure. Hitris and Posnett (1992) used 560 pooled time series and cross section observation from two OECD countries over the period 1960-1987 and found a strong and positive relationship between per capita health spending and GDP.

\section{EMPIRICAL MODEL}

Following Hoeffler (2002), the Solow model growth in output per worker depends on initial output per worker $[\mathrm{y}(0)]$, the initial level of technology $[\mathrm{A}(0)]$, the rate of technological progress $(\mathrm{g})$, the savings rate (s), the growth rate of the labour force $(\mathrm{n})$, the depreciation rate 
$(\delta)$, and the share of capital in output $(\alpha)$. Thus, the model predicts that a high saving rate will affect growth in output per worker positively, whereas high labour force growth (corrected by the rate of technological progress and the rate of depreciation) will have a negative effect on growth in output per worker. The basic Solow model is:

$$
\begin{aligned}
& \ln y(t)-\ln y(0)=\ln y(0)+\ln A(0) \\
& +g t+\frac{\alpha}{1-\alpha} \ln (s)-\frac{\alpha}{1-\alpha} \ln (n+g+\delta)
\end{aligned}
$$

where $y(t)$ denotes the logarithm of output per worker in period $t$.

In the augmented version of the Solow model investment in human capital is an additional determinant of growth in output per worker:

$$
\begin{aligned}
& \ln y(t)-\ln y(0)=\ln y(0)+\ln A(0)+g t+\frac{\alpha}{1-\alpha-\beta} \ln \left(s_{k}\right) \\
& +\frac{\beta}{1-\alpha-\beta} \ln \left(s_{h}\right)-\frac{\alpha}{1-\alpha} \ln (n+g+\delta)
\end{aligned}
$$

where $s_{k}$ and $s_{h}$ denote the proportion of output invested in physical and human capital, respectively.

Equations (1) and (2) have for example, been used as the framework for empirical analysis by Mankiw, Romer, and Weil (1992), Islam (1995), and Caselli et al. (1996). In this section, a simple model is set out that provides an organising framework for thinking about the ways in which the elements and components of fiscal policy affect growth. Therefore, this study adopted the framework introduced by Mankiw et al. (1992), Demetriades and Law (2006), Ghura and Hadjimichael (1996), Hoeffler (2002), and Knight, Loayza, and Villanueva (1993). This study provided a growth model from the conventional growth accounting framework and the production function below takes the standard neoclassical form with a minor modification which includes human capital in the Cobb-Douglas production function:

$Y(t)=K(t)^{\alpha} H(t)^{\beta}[A(t) L(t)]^{1-\alpha-\beta}, 0<\alpha<1$.

where $Y$ is real output at time $t, K$ and $L$ are the stocks of physical capital and labour, respectively, at time $t, H$ is the stock of human capital, $A$ is a similar measure for physical capital, and $\alpha$ and $\beta$ the share of capital and human capital on output. $A$ is a labour-augmenting factor reflecting the level of technological development and efficiency in the economy and the subscript $t$ indicates time. This equation states merely that at any moment, the total output of the economy depends on the quantity and quality of physical capital employed, the quantity of labour employed, and the average level of skills of the labour force. Output can only increase if $K, L, A$, or $H$ also increases, and perpetual increases in output per worker can only occur if the stock of capital per worker or the average quality of labour or of capital also increases perpetually.

It was assumed that $\alpha+\beta<1$ implies that there are decreasing returns to all capital raw labour and labour-augmenting technologies are assumed to grow according to the following functions:

$L(t)=L(0) e^{n t}$

$\mathrm{A}(\mathrm{t})=\mathrm{A}(0) \mathrm{e}^{\mathrm{gt}}+{ }^{\mathrm{P \theta}}$

where $n$ is the exogenous rate of growth of the labour force, $g$ is the exogenous rate of technological progress, $P$ is variables of vector of fiscal policy that can affect the level of technology and efficiency in the economy, and $\theta$ is a vector of coefficient related to these variables.

Demetriades and Law (2006) stated that variable $A$ depends on exogenous technological improvements and the level of other variables. Variable $A$ in this study is differing from $A$ used by Mankiw et al. (1992). This modification is more likely to be particularly relevant to the empirical cases of the link between component of fiscal policies and economic growth. The technological improvements are encouraged by development in public investment spending and fiscal policy which tend to contribute to economic growth (Ramirez \& Nazmi, 2003).

In the steady state, output per worker grows at the constant rate $g$, which is the exogenous component of the growth rate of the efficiency variable $A$ (Demetriades \& Law, 2006). Hence, this output can be obtained directly from the definition of output per effective worker as follows: 


\section{$\frac{Y(t)}{A(t) L(t)}=[k(t)]^{\alpha}[h(t)]^{\beta}$}

$\frac{Y(t)}{L(t)}=A(t)[k(t)]^{\alpha}[h(t)]^{\beta}$

Let $y_{t}^{*}=\left(\frac{Y(t)}{L(t)}\right)^{*}$

Taking logs both of Equation (6) and log income per worker at a given time; time 0 for simplicity is

$\ln \left(\frac{Y}{L}\right)^{*}=\ln A+\alpha \ln k^{*}+\ln \beta \ln h^{*}$

Where $A(t)=A(0) e^{g t+P \theta}$

The main equation of this model used for estimation purposes in equation (8) below:

$$
\begin{gathered}
\ln \left(\frac{Y}{L}\right)^{*}=\ln A_{b}+g t+\theta \ln P+\frac{\alpha}{1-\alpha-\beta} \ln s_{k} \\
+\frac{\beta}{1-\alpha-\beta} \ln s_{h}-\frac{\alpha+\beta}{1-\alpha-\beta} \ln (n+g+\delta)
\end{gathered}
$$

Equations (8) indicates steady state output per worker or labour productivity where a vector of and fiscal policies proxies exist, while $s_{k}$ is the savings in physical capital, $s_{h}$ is the savings in human capital, and $\delta$ is the rate of depreciation.

Before proceeding to estimate the model, it is necessary to write Equation (8) in terms of per capita output. Note again that for Mankiw et al. (1992):

$\ln A(0)=\alpha+\varepsilon$

On the other hand, for Islam (1995) and Caselli et al. (1996):

$\ln A(t)=\ln A(0)+g t$

Out model differs from Caselli et al. (1996) and Islam (1995) where it was assumed that $s_{h}$ and $g t$ do not vary over time but $s_{k}$ and $n$ can be assumed to vary over time. This means that $\ln A_{0}$, $g t$ and can be considered as a constant term $A_{0}$. Therefore, the steady-state output per worker or labour productivity $\left(y^{*}\right)$ grows according to the following equation:

$$
\begin{aligned}
\ln \left(\frac{Y}{L}\right)^{*}= & A_{b}+\theta \ln P+\frac{\alpha}{1-\alpha-\beta} \ln s_{k} \\
& +-\frac{\alpha+\beta}{1-\alpha-\beta} \ln (n+g+\delta)
\end{aligned}
$$

The above equation introduces a set of variables $(P)$ which is assumed as exogenous that could affect economic growth in the long-run. With the introduction of endogenous growth theory, $P$ is no longer assumed as exogenous. The endogenous treatment of $P$ allows us to suggest a possible set of explanatory variables. This model differs from neoclassical production functions in two important categories of variables namely technology related variables and policy related variables. The key assumption about productivity growth here is that a typical developing county purchases technology knowledge abroad from various suppliers. What technology will be purchased depends on the price of foreign technology as well as trade and exchange rate policies that impact the final cost of the imported technology (Ramirez \& Nazmi, 2003). In our model, we concentrated on policy related variables and we introduced fiscal policy inclusion as a proxy for policy related variables.

Therefore, we proposed the Basic Model:

$$
\begin{aligned}
\ln Y_{i t}= & \beta_{o}+\beta_{1} \ln G O V P O L_{i t}+\beta_{2} \ln S_{k i t} \\
& -\beta_{3} \ln (n+g+\delta)_{i t}
\end{aligned}
$$

where $\mathrm{Y}_{\text {it }}$ is real GDP per capita, GOVPOL $L_{i t}$ is a control variables of fiscal policy, $S_{k i t}$ is the savings in physical capital, $(\mathrm{n}+\mathrm{g}+\delta): n$ is the rate of labour growth, $g$ is the rate of technology growth or technological progress, and $\delta$ is the rate of depreciation. The addition of $g$ and $\delta$ is assumed to be constant across countries and over time, following Islam (1995), Mankiw et al. (1992), and Caselli et al. (1996), technological progress and the depreciation rate were assumed to be constant across countries and that they sum up to 0.05 . The natural logarithm of the sum of population growth and 0.05 was calculated for $\ln (n+g+\delta)$. $\delta_{0}$ is a constant term and $\beta_{1}, \beta_{2}$, and $\beta_{3}$ are estimated parameters in the model. 
As with studies of the impact of health, education, and defence expenditures on economic growth, some dispersion of results is a natural outcome of differences in data sets and specifications. Given the above discussion and equation (12), the proposed empirical Model 1 is as follows for the effect of components of government expenditure on economic growth:

$$
\begin{aligned}
\ln Y_{i t}= & \beta_{0}+\beta_{1} \ln h e_{i t}+\beta_{2} \ln e e_{i t}+\beta_{3} \ln d e_{i t} \\
& +\beta_{4} \ln O F V_{i t} \beta 5 \ln S_{k i t}-\beta_{6} \ln (n+g+\delta)_{i t} \\
& +\varepsilon_{i t}
\end{aligned}
$$

where $Y_{i t}$ is real GDP per capita, $h e_{\text {it }}$ is a government expenditure on health to GDP, $e e_{i t}$ represents government expenditure on education to GDP, $d e_{i t}$ is a government expenditure on defence to GDP, $\mathrm{OFV}_{\text {it }}$ is an aggregate of independent other fiscal variables as a share of GDP (obtained by summing up public sector wages and salaries, expenditure on other goods and services, transfers and subsidies, interest payment on government debt, capital expenditure (minus government expenditure on health, education and defence), tax revenues, nontax revenue, and grant), $S_{k i t},(n+g+\delta)$ and are as defined earlier in equation (12), $i$ is a crosssection data for countries referred to, and $t$ is a time series data, $\varepsilon_{\text {it }}$ is an error term. The constant is denoted $\beta_{0}$ while $\beta_{1}-\beta_{6}$ are the coefficients showing how much a one unit increase in each individual variable will affect the growth rate in economic growth.

From equation (12) also, we proposed empirical Model 2 for the effect of fiscal policy on economic growth, as follows:

$$
\begin{aligned}
\ln Y_{i t}= & \beta_{0}+\beta_{1} \ln d t_{i t}+\beta_{2} \ln b b_{i t}+\beta_{3} G E_{i t} \\
& +\beta_{4} \ln S_{k i t}-\beta_{5} \ln (n+g+\delta)_{i t}+\varepsilon_{i t}
\end{aligned}
$$

where $Y_{i t}$ is real GDP per capita, $d t_{i t}$ is a distortionary taxation as a share of GDP (obtained by taxes on income and profit + social contribution + taxes on payroll and + taxes on property), $b b_{i t}$ represents budget balance as a share of GDP [obtained by $(\operatorname{tax}$ revenue + nontax revenue + grants $)$ - (current expenditure + capital expenditure (minus government expenditure on health, education and defence)], $G E_{i t}$ is an aggregate of independent government expenditure variables as a share of GDP (obtained by summing up the government expenditure on health, education, and defence), $S_{k_{i t}}$ and $(n+g+\delta)_{i t}$ are as defined earlier in equation (12), $i$ is a cross-section data for countries referred to, and $t$ is a time series data, $\varepsilon_{i t}$ is an error term. The constant is denoted as $\beta_{0}$ while $\beta_{1}-\beta_{5}$ are the coefficients showing how much a one unit increase in each individual variable will affect the growth rate in economic growth.

\section{Panel Unit Root Tests Estimation}

Before testing for cointegration we need to confirm whether the variables are actually nonstationary. We adopted the approach suggested by Levin, Lin, and Chu (2002; henceforth LLC), Im, Pesaran, and Shin (1997; henceforth IPS), and Maddala and Wu (1999; henceforth MW), which is based on the well-known Dickey-Fuller procedure.

We start with LLC who found that the main hypothesis of panel unit root is as follows:

$\Delta \mathrm{y}_{\mathrm{it}}=\Phi_{\mathrm{i}} \mathrm{y}_{\mathrm{i}, \mathrm{t}-1}+\sum_{\mathrm{t}=1}^{\mathrm{p}_{\mathrm{i}}} \rho_{\mathrm{i}, \mathrm{I}} \Delta \mathrm{y}_{\mathrm{i}, \mathrm{t}-\mathrm{L}}+\varepsilon_{\mathrm{i}, \mathrm{t}}$

$m=1,2, \ldots$

where $y_{i, t}$ refers to variable $\ln r g d p c_{i t}, \ln h e_{i t}, \ln e e_{i t}$ , $\ln d e_{i t}, \ln g e_{i t}, \ln O F V_{i t}, \ln s_{k_{i t}} \ln (n+g+\delta)_{i t}$, and $\Delta$ refers to the first difference. The hypothesis test is $H_{0}: \Phi_{\mathrm{i}}<0$ for existence of unit root whereas $H_{a}$ : $\Phi_{\mathrm{i}}<0$ for all $i$ for non-existence of unit root.

IPS proposed a test for the presence of unit roots in panels that combines information from the time series dimension with that from the cross section dimension, such that fewer time observations are required for the test to have power. Since the IPS test has been found to have superior test power by researchers in economics to analyse long-run relationships in panel data, we also employed this procedure in this study. IPS begins by specifying a separate ADF regression for each cross-section with individual effects and no time trend: 
$\Delta y_{i t}=\alpha_{i}+\rho_{i} y_{i, t-1}+\sum_{j=1}^{p_{i}} \beta_{i j} \Delta y_{i, t-j}+\varepsilon_{i t}$

where $i=1, \ldots, N$ and $t=1, \ldots, T$

IPS uses separate unit root tests for the $N$ cross-section units. Their test is based on the Augmented Dickey-fuller (ADF) statistics averaged across groups. After estimating the separate ADF regressions, the average of the $t$-statistics for $p_{1}$ from the individual ADF regressions, $t_{i T i}\left(P_{i}\right)$ is:

$$
\bar{t}_{N T}=\frac{1}{N} \sum_{i=1}^{N} t_{i T}\left(p_{i} \beta_{i}\right)
$$

The $t$-bar is then standardised and it is shown that the standardised t-bar statistic converges to the standard normal distribution as $\mathrm{N}$ and $\mathrm{T} \rightarrow \infty$.

Finally, MW developed a test based in the probability values of all root unit individual tests. An alternative approach to panel unit root tests uses Fisher's (1932) results to derive tests that combine the $p$-values from individual unit root tests. The statistic is given by:

$-2 \sum_{i=1}^{N} \log \left(\pi_{i}\right) \rightarrow \chi_{2 N}^{2}$

where $\pi_{\mathrm{i}}$ is the $\mathrm{p}$-value of the test statistic in unit $i$, and is distributed as $\chi^{2}(2 N)$ under the usual assumption of cross-sectional independence. When the Fisher test is based on ADF test statistics, we must specify the number of lags used in each cross-section ADF regression. Maddala and $\mathrm{Wu}$ (1999) showed that it is more powerful than the $t$-bar in IPS test.

\section{Panel Cointegration Tests Estimation}

The next step is to test for the existence of a long-run relationship among real per capita GDP growth rates and the independent variables using seven panel cointegration tests suggested by Pedroni (1999).

The procedures proposed by Pedroni make use of estimated residual from the hypothesised long-run regression of the following form (Pedroni, 1999): $y_{i, t}=\alpha_{i}+\delta_{i} t+\beta_{1 i} x_{1 i, t}+\beta_{2 i} x_{2 i, t}$

$+\ldots+\beta_{M i} x_{M i, t}+e_{i, t}$

for $t=1, \ldots, T ; i=1, \ldots, N ; m=1, \ldots, M$,

where $T$ is the number of observations over time, $N$ number of cross-sectional units in the panel, and $M$ number of regressors. In this set up, $\alpha_{i}$ is the member specific intercept or fixed effects parameter which varies across individual crosssectional units. The same is true of the slope coefficients and member specific time effects, $\delta_{i} t$.

The asymptotic distributions of these panel cointegration statistics are derived in Pedroni (2004). Under appropriate standardisation, based on the moments of the vector of Brownian motion functionals, these statistics are distributed as standard normal. The standardisation is given by:

$$
K=\left[k_{N T}-\mu \sqrt{N}\right] / \sqrt{v}
$$

Pedroni (1999) gave critical values for $\mu$ and $v$ with and without intercepts, and deterministic trends. The small sample size and power properties of all seven tests are discussed in Pedroni (2004). He found that size distortions are minor, and power is high for all statistics when the time span is long. For shorter panels, the evidence is more varied. However, in the presence of a conflict in the evidence provided by each of the statistics, Pedroni showed that the group-adf statistic and panel- $a d f$ statistic generally perform best.

\section{Fully Modified Ordinary Least Squares (FMOLS) Estimation}

In this section, we adopted FMOLS procedure from Christopoulos and Tsionas (2003, 2004). In order to obtain asymptotically efficient consistent estimates in panel series, nonexogeneity, and serial correlation problems are tackled by employing fully modified OLS (FMOLS) introduced by Pedroni (1996). Since the explanatory variables are cointegrated with a time trend, and thus a long-run equilibrium relationship exists among these variables through the panel unit root test and panel cointegration test, we proceeded to estimate the equation (13) 
to equation (14) by the method or fully modified OLS (FMOLS) for heterogenous cointegrated panels (Pedroni, 1996, 2000). This methodology allows consistent and efficient estimation of the cointegration vector and also addresses the problem of non-stationary regressors, as well as the problem of simultaneity biases. It is well known that OLS estimation yields biased results because the regressors are endogenously determined in the $I(1)$ case. The starting point OLS as in the following cointegrated system for panel data is:

$\mathrm{y}_{\mathrm{it}}=\alpha_{\mathrm{i}}+\mathrm{x}_{\mathrm{it}}^{\prime} \beta+\mathrm{e}_{\mathrm{it}}$

$x_{i t}=x_{i, t-1}+\varepsilon_{i t}$

where $\xi_{i t}=\left[e_{i t}, \varepsilon_{i t}^{\prime}\right]$ is the stationary with covariance matrix $\Omega_{\mathrm{i}}$. The estimator $\beta$ will be consistent when the error process $\omega_{i t}+\left[e_{i t}, \varepsilon_{i t}{ }_{i t}{ }^{\prime}\right.$ satisfies the assumption of cointegration between $y_{i t}$ and $x_{i t}$. The limiting distribution of OLS estimator depends upon nuisance parameters. Following Phillips and Hansen (1990), a semi-parametric correction can be made to the OLS estimator that eliminates the second order bias caused by the fact that the regressors are endogenous. Pedroni (1996, 2000) followed the same principle in the panel data context, and allowed for the heterogeneity in the short-run dynamics and the fixed effects. FMOLS Pedroni's estimator is constructed as follows:

$$
\begin{aligned}
& \hat{\beta}_{F M}-\beta=\left(\sum_{i=1}^{N} \hat{\Omega}_{22 i}^{-2} \sum_{t=1}^{T}\left(x_{i t}-\hat{x}_{t}\right)^{2}\right)^{-1} \sum_{i=1}^{N} \hat{\Omega}_{11 i}^{-1} \hat{\Omega}_{22 i}^{-1} \\
& \left(\sum_{t=1}^{T}\left(x_{i t}-\bar{x}_{t}\right) e_{i t}^{*}-T \hat{\gamma}_{i}\right) \\
& \hat{e}_{i t}^{*}=e_{i t}-\hat{\Omega}_{22 i}^{-1} \hat{\Omega}_{21 i}, \quad \hat{\gamma}_{i}=\hat{\Gamma}_{21 i}+\hat{\Omega}_{21 i}^{0}-\hat{\Omega}_{22 i}^{-1} \hat{\Omega}_{21 i}\left(\hat{\Gamma}_{22 i}+\hat{\Omega}_{22 i}^{0}\right)
\end{aligned}
$$

where the covariance matrix can be decomposed as $\Omega_{\mathrm{i}}=\Omega_{\mathrm{i}}^{0}+\Gamma_{\mathrm{i}}+\Gamma_{\mathrm{i}}$ where $\Omega_{\mathrm{i}}^{0}$ is the contemporaneous covariance matrix, and $\Gamma_{i}$ is a weighted sum of autocovariances. Also, $\hat{\Omega}_{\mathrm{i}}^{0}$ denotes an appropriate estimator of $\Omega_{\mathrm{i}}^{0}$.

In this study, we employed both the within-dimension and between-dimension panel FMOLS test from Pedroni (1996, 2000). An important advantage of the between-dimension estimators is that the form in which the data is pooled allows for greater flexibility in the presence of heterogeneity of the cointegrating vectors. Specifically, whereas test statistics constructed from the within-dimension estimators are designed to test the null hypothesis $H_{0}: \beta_{i}=$ $\beta_{0}$ for all $I$ against the alternative hypothesis $H_{A}$ $: \beta_{i}=\beta_{A} \neq \beta_{0}$ where the value $\beta_{A}$ is the same for all $i$, test statistics constructed from the betweendimension estimators are designed to test the null hypothesis $H_{0}: \beta_{i}=\beta_{0}$ for all $i$ against the alternative hypothesis $H_{A}: \beta_{i} \neq \beta_{0}$, so that the values for $\beta_{i}$ are not constrained to be the same under the alternative hypothesis. Clearly, this is an important advantage for applications such as the present one, because there is no reason to believe that, if the cointegrating slopes are not equal to one, they may take on some other arbitrary common value. Another advantage of the between-dimension estimators is that the point estimates have a more useful interpretation in the event that the true cointegrating vectors are heterogeneous. Specifically, point estimates for the between-dimension estimator can be interpreted as the mean value for the cointegrating vectors. This is not true for the within-dimension estimators (Pedroni, 2001).

\section{Data and Choice of Variables}

The data set consists of a panel of observations for 13 Asian countries namely China, Hong Kong, Korea, Japan, Indonesia, Malaysia, Philippines, Singapore, Thailand, Bangladesh, India, Pakistan, and Sri Lanka for the period 1982-2001. Annual data on real GDP, real per capita GDP, government expenditure on defence, education and on health, distortionary taxation, and budget balance (all expressed as ratios to GDP) are collected from the World Development Indicator from World Bank CDROM 2004 and 2005, Asian Development Bank, 2004, and The Government Finance Statistics. All these data were converted to US dollars based on 2000 constant prices. We also used an aggregate of independent government expenditure variables as a share of GDP and an aggregate of independent other fiscal variables as a share of GDP. We proxied the saving rate by the aggregate investment (real gross capital formation) to GDP ratio and proxied the average of the total labour force as an average population 
growth rates. Like Islam (1995), Mankiw et al. (1992), and Caselli et al. (1996), technological progress and the depreciation rate were assumed to be constant across countries and that they sum up to 0.05 . The natural logarithm of the sum of population growth and 0.05 was calculated for $\ln (n+g+\delta)$.

\section{RESULTS}

Table 1 presents the results of the LLC, IPS, and MW panel unit root tests at level indicating that all variables are $I(0)$ in the constant of the panel unit root regression. These results clearly showed that the null hypothesis of a panel unit root in the level of the series cannot be rejected at various lag lengths. It was assumed that there is no time trend. Therefore, we tested for stationarity allowing for a constant plus time trend. In the absence of a constant plus time trend, again we found that the null hypothesis of a having a panel unit root is generally rejected in all series at level form and various lag lengths.

Table 2 presents the results of the tests at first difference for LLC, IPS and MW tests in constant and constant plus time trends. We can see that for all series the null hypothesis of unit root test is rejected at $95 \%$ critical value (1\% level). Hence, based on LLC, IPS, and MW tests, there is strong evidence that all the series are in fact integrated of order one. We can conclude that the results of panel unit root tests (LLC, IPS, and MW tests) reported in fact integrated of order one.

Table 1

Panel Unit Root Tests: Level

\begin{tabular}{lcccccc}
\hline & \multicolumn{3}{c}{ CONSTANT } & \multicolumn{3}{c}{ CONSTANT + TREND } \\
& LLC & IPS & MW & LLC & IPS & MW \\
\hline $\ln r g d p c$ & $-0.35(5)$ & $1.72(0)$ & $21.81(1)$ & $2.1192)$ & $1.15(1)$ & $30.44(1)$ \\
$\ln h e$ & $3.39(8)$ & $3.40(0)$ & $12.39(0)$ & $0.52(0)$ & $2.19(0)$ & $18.80(0)$ \\
$\ln e e$ & $-1.32(0)$ & $3.23(0)$ & $15.01(0)$ & $2.17(0)$ & $2.57(0)$ & $20.87(0)$ \\
$\ln d e$ & $-0.58(0)$ & $3.74(2)$ & $23.82(3)$ & $0.08(0)$ & $1.49(0)$ & $20.89(0)$ \\
$\ln d t$ & $-2.36(0)$ & $-0.83(0)$ & $23.92(0)$ & $-0.76(0)$ & $-0.57(0)$ & $26.79(0)$ \\
$\ln b b$ & $-0.74(2)$ & $-0.91(1)$ & $33.98(1)$ & $1.19(2)$ & $-0.68(2)$ & $28.15(2)$ \\
$\ln G E$ & $-1.52(0)$ & $3.52(0)$ & $17.41(0)$ & $3.34(0)$ & $1.58(1)$ & $13.73(1)$ \\
$\ln$ OFV & $-0.99(0)$ & $3.51(0)$ & $9.33(0)$ & $0.42(1)$ & $-0.59(0)$ & $25.08(1)$ \\
$\ln s_{k}$ & $0.10(0)$ & $-0.71(0)$ & $33.11(0)$ & $1.73(2)$ & $-0.03(0)$ & $25.25(0)$ \\
$\ln (n+g+\delta)$ & $-1.08(2)$ & $-0.51(4)$ & $22.38(4)$ & $0.12(2)$ & $-0.77(2)$ & $28.97(2)$ \\
\hline
\end{tabular}

Notes: The number in ( ) denote lag length. The lag length is chosen on the basis of the Akaike's Information Criteria (AIC) where we specified maximum lag order (k) in autoregression and then we selected appropriate lag order according to the AIC.

For LLC $t$-stat all reported values are distributed $\mathrm{N}(0,1)$ under null of unit root or no cointegration.

Table 2 supports the hypothesis of a unit root in all variables across countries, as well as the hypothesis of zero order integration in first differences. At most of the $1 \%$ significance level, we found that all tests statistics in both with and without trends significantly confirm that all series strongly reject the null of unit root. The presence of unit root in the variablesalso indicated that all the independent variables (ln $h e, \ln e e, \ln d e, \ln d t, \ln b b$,$) [ \ln G E, \ln O F V$, $\left.\ln s_{k}, \ln (n+g+\delta),\right]$ and dependent variables $\ln$ $\operatorname{rgdpc}$ ) are in fact integrated of order one or are 
$I(1)$ processed when the individual country data were pooled together. The findings of a unit root on the variables in this study were consistent with the results of a number of previous studies such as Campbell and Perron (1991), McCoskey and Selden (1998), MacDonald and Nagayasu
(2000), Lee and Chang (2006), and Al-Awad and Harb (2005). Given the results of LLC, IPS, and MW tests, it is possible to apply panel cointegration methodology in order to test for the existence of the stable long-run relation among the variables.

Table 2

Panel Unit Root Tests: First Difference

\begin{tabular}{lcccccr}
\hline & \multicolumn{3}{c}{ CONSTANT } & \multicolumn{3}{c}{ CONSTANT + TREND } \\
& LLC & \multicolumn{1}{c}{ IPS } & MW & LLC & IPS & MW \\
\hline $\ln r g d p c$ & $-7.51(0)^{*}$ & $-5.57(0)^{*}$ & $75.95(0)^{*}$ & $-8.25(0)^{*}$ & $-5.30(0)^{*}$ & $71.07(0)^{*}$ \\
$\ln h e$ & $-10.56(0)^{*}$ & $-10.14(0)^{*}$ & $137.29(0)^{*}$ & $-11.47(0)^{*}$ & $-9.67(0)^{*}$ & $121.72(0)^{*}$ \\
$\ln e e$ & $-7.75(0)^{*}$ & $-8.69(0)^{*}$ & $118.59(0)^{*}$ & $-7.58(0)^{*}$ & $-7.63(0)^{*}$ & $99.14(0)^{*}$ \\
$\ln d e$ & $-11.06(0)^{*}$ & $-10.09(0)^{*}$ & $135.84(0)^{*}$ & $-11.51(0)^{*}$ & $-9.81(0)^{*}$ & $122.65(0)^{*}$ \\
$\ln d t$ & $-12.73(0)^{*}$ & $-12.48(0)^{*}$ & $169.97(0)^{*}$ & $-11.58(0)^{*}$ & $-10.92(0)^{*}$ & $134.49(0)^{*}$ \\
$\ln b b$ & $-17.06(0)^{*}$ & $-15.83(0)^{*}$ & $214.48(0)^{*}$ & $-14.57(0)^{*}$ & $-13.67(1)^{*}$ & $166.69(0)^{*}$ \\
$\ln G E$ & $-5.00(0)^{*}$ & $-4.69(0)^{*}$ & $67.90(0)^{*}$ & $-5.49(0)^{*}$ & $-3.78(0)^{*}$ & $56.40(0)^{*}$ \\
$\ln O F V$ & $-14.17(0)^{*}$ & $-12.74(0)^{*}$ & $172.04(0)^{*}$ & $-13.29(0)^{*}$ & $-11.77(0)^{*}$ & $144.00(0)^{*}$ \\
$\ln s_{k}$ & $-10.64(0)^{*}$ & $-9.03(0)^{*}$ & $121.18(0)^{*}$ & $-9.42(0)^{*}$ & $-6.53(0)^{*}$ & $85.39(0)^{*}$ \\
$\ln (\mathrm{n}+\mathrm{g}+\delta)$ & $-19.09(0)^{*}$ & $-17.09(0)^{*}$ & $230.74(0)^{*}$ & $-16.87(0)^{*}$ & $-15.26(0)^{*}$ & $185.03(0)^{*}$ \\
\hline
\end{tabular}

Notes: The number in ( $)$ denote lag length. The lag length is chosen on the basis of the Akaike's Information Criteria (AIC) where we specified maximum lag order (k) in autoregression and then we selected appropriate lag order according to the AIC.

For LLC $t$-stat all reported values are distributed $\mathrm{N}(0,1)$ under null of unit root or no cointegration.

\section{Panel Cointegration Tests}

The next step is to test whether the variables are cointegrated using Pedroni's (1999, 2001, 2004) methodology as described previously for Model 1 and Model 2. This is to investigate whether longrun steady state or cointegration exists among the variables and to confirm what $\mathrm{Oh}$, Kim, Kim, and Ahn (1999), and Coiteux and Olivier (2000) stated that the panel cointegration tests have much higher testing power than conventional cointegration test. Since the variables were found to be integrated in the same order $I(1)$, we continued with the panel cointegration tests proposed by Pedroni (1999, 2001, 2004). Cointegrations were carried out for constant and constant plus time trends and the summary of the results of cointegrations analyses are presented in Table 3.
In constant level, we found that Model 1 and Model 2 indicated only one (1) statistic that rejected null by hypothesis of no cointegration at the $1 \%$ level of significance, which is panel- $v$. This result still implied that independent variables do hold cointegration in the long-run for a group of 13 Asian countries with respect to real per capita GDP. In the panel cointegration test for Model 1 and Model 2 with constant plus trend level, the results indicated that three out of seven statistics rejected the null hypothesis of non-cointegration at the $1 \%$ level of significance. It was also shown that independent variables do hold cointegration in the long-run for a group of 13 Asian countries with respect to real per capita GDP.

Overall in Table 3, we found that most of the panel and group statistics are more reliable in 
constant plus time trend compared to the panel and group statistics in constant. For smaller $T$ the panel non-parametric ( $t$-statistic) and parametric (adf-statistic) statistics as well as group statistics that are analogous to the IPS-test statistics, the null hypothesis of non-cointegration was rejected; the panel variance and group rho tended to perform poorly. However, since three out of seven statistics conclude in favour of cointegration, and this, combined with the fact that the according to Pedroni (1997) the panel-adf and the group-adf statistics are more reliable and also the panel variance even though its performs poorly, we concluded that there is a cointegrating relationship among our variables. These results also implied that taken as a group, the theory of growth through augmented Solow model for Model 1 and Model 2 does hold over the estimation period.

Table 3

Panel Cointegration Tests for Heterogeneous Panel; Dependent Variable: Real Per Capita GDP

\begin{tabular}{lcccc}
\hline & \multicolumn{2}{c}{ Constant } & \multicolumn{2}{c}{ Constant + Trend } \\
& Model 1 & Model 2 & Model 1 & Model 2 \\
\hline Panel- $v$ & $2.06^{*}$ & $2.62^{*}$ & $3.61^{*}$ & $3.27^{*}$ \\
Panel- $\rho$ & 3.27 & 3.53 & 4.08 & 4.45 \\
Panel- $t$ & 2.37 & 2.62 & 3.53 & 3.13 \\
Panel- $a d f$ & 2.50 & 2.96 & 3.96 & 3.11 \\
Group- $\rho$ & 4.33 & 4.11 & 4.56 & 4.28 \\
Group- $t$ & 1.98 & 2.33 & $-2.45^{*}$ & 2.56 \\
Group- $a d f$ & 1.94 & 1.68 & $-2.12^{*}$ & 2.66 \\
\hline
\end{tabular}

Notes. All statistics are from Pedroni's procedure (1999) which is the adjusted values can be compared to the $\mathrm{N}(0,1)$ distribution. The Pedroni (2004) statistics are one-sided tests with a critical value of $-1.64(k<-1.64$ implies rejection of the null), except the panel $v$-statistic that has a critical value of $1.64(k>1.64$ suggests rejection of the null).

$*, * *$ indicates rejection of the null hypothesis of non-cointegration at $1 \%$ and $5 \%$ levels of significance.

Cointegration Estimation Results - FMOLS

The previous section already confirmed that all variables in two equations (two models) are cointegrated. In other words, there longrun equilibrium exists among the variables. This section discusses the estimated long-run equation. Following Pedroni (2000, 2001), cointegrating explanatory variables for the data were estimated using the Fully Modified OLS (FMOLS) technique. In Table 4 and Table 5, results are reported for within group (withindemension) FMOLS and panel group (betweendimension) FMOLS estimators without and with common time dummies.
Table 4 shows the within group FMOLS results without time dummies and all variables in Model 1 reported tests that reject the null hypotheses at the $1 \%$ and $5 \%$ levels of significance. Additionally Table 4 also (panel group FMOLS) shows that all variables in Model 1 reported tests that reject the null hypotheses at the $1 \%$ and $5 \%$ levels of significance. For within group, the estimate of coefficient for government expenditure on health (ln he), and government expenditure on education ( $\ln e e$ ), and the estimate of the coefficient were positive (1.16 and 0.27) and statistically significant at the 5\% level. Panel group shows that the estimation coefficients for 
government expenditure on health ( $\ln h e)$ and government expenditure on education ( $\ln$ ee) were positive (1.81 and 0.42) and statistically significant at the $1 \%$ level. Results in Table 4 shows that education and health expenditures increase economic growth, which means that there is a long-run cointegration between education and health expenditures, and economic growth.

For defence expenditure (ln $d e$ ) in Model 1 , it also rejected the null hypotheses of noncointegration, and the coefficient is negative $(-7.16$ and -6.85$)$ and statistically significant at $1 \%$ level. We concluded that results in both tables show that increase in defence expenditures will decrease economic growth, which means that there is still a long-run cointegration between health expenditures and economic growth, and defence expenditure has an adverse effect on economic growth.

The estimated coefficient for the aggregate of other fiscal variables (ln $O F V$ ) in both groups were positive (0.02) and statistically significant at the 5\% level for both models in within group and statistically significant at the $1 \%$ level in panel group. The results in both tables show that the aggregate of other fiscal variables positively affect growth, meaning that there is a long-run cointegration between the aggregate of other fiscal variables and economic growth.

Table 4 exhibits that the estimated coefficient for the savings in physical capital (investment) ( $\ln \mathrm{s}_{\mathrm{k}}$ ) was positive (0.12) for Model 1 in within group and statistically significant at the 5\% level, while the estimated coefficient for the savings in physical capital (investment) $\left(\ln s_{k}\right.$ ) was positive (0.08) for Model 1 in panel group and statistically significant at the $1 \%$ level. We concluded that investment in these models is one of the strongest correlations of economic growth; which means there is a long-run cointegration. In Table 4, the coefficient on population growth $(\ln (n+g+\delta)$ was negative [-0.31 and -0.29] and statistically significant at the 5\% level in within group and statistically significant at the $1 \%$ level in panel group. We concluded that results in both tables show that increase in population growth will decrease economic growth, meaning that there is still a long-run cointegration between population growth and economic growth, and population growth has an adverse effect on economic growth.

In Model 2, there was a negative coefficient (-3.44 and -2.57) which was statistically significant at the $1 \%$ level for the distortionary taxation (ln $d t)$ in within group and panel group. The estimated coefficient of the budget balance $(\ln b b)$ was also negative (-0.02 and -0.06) and statistically significant at the $5 \%$ level in within group and statistically significant at the $1 \%$ level in panel group. The results in both groups showed that the distortionary taxation and budget balance have an adverse effect on economic growth, which means that there is a long-run cointegration between the distortionary taxation and budget balance, and economic growth.

In Model 2, the estimate of the coefficient for the aggregate of government expenditure (ln $G E$ ) was positive (2.08 and 0.02 ) and statistically significant at the $1 \%$ level. We concluded that there is presence of a long-run relationship between GDP and government expenditure. The estimated coefficient for the savings in physical capital (investment) $\left(\ln _{s k}\right)$ was positive $(0.14)$ and statistically significant at the 5\% level in within group, and statistically significant at the $1 \%$ level in panel group. These results were the same in Model 1 and we concluded that investment and economic growth have a long-run cointegration. The coefficient on population growth $(\ln (n+g+\delta)$ was negative $(-0.21)$ and statistically significant at the $5 \%$ level in within group, while the coefficient on population growth $(\ln (n+g+\delta)$ was also negative (-0.29) and statistically significant at the $1 \%$ level in panel group. Model 1 results in both groups showed that there is still a long-run cointegration between population growth and economic growth, and population growth has an adverse effect on economic growth.

Comparing the results reported in within group and panel group, we found that the panel groups gave higher values of estimation coefficient and higher values of significance ( $1 \%$ level) which would be a more accurate representation of the average long-run relationship. Therefore, we concluded that all variables were cointegrated and there was a long-run relationship. 
Table 4

FMOLS Results, without Time Dummies: Dependent Variable: Real Per Capita GDP

\begin{tabular}{lcccc}
\hline & \multicolumn{2}{c}{ Within Group } & \multicolumn{2}{c}{ Panel Group } \\
& Model 1 & Model 2 & Model 1 & Model 2 \\
\hline $\ln h e$ & $1.16^{* *}(2.61)$ & - & $1.81 *(-3.26)$ & - \\
$\ln e e$ & $0.27 * *(2.82)$ & - & $0.42 *(-3.25)$ & - \\
$\ln d e$ & $-7.16^{*}(-5.61)$ & - & $-6.85 *(-5.85)$ & - \\
$\ln d t$ & - & $-3.44 *(-4.44)$ & - & $-2.57 *(8.24)$ \\
$\ln b b$ & $-0.02 * *(-2.54)$ & - & $-0.06 *(-6.12)$ \\
$\ln G E$ & - & $2.08 *(-3.47)$ & - & $0.02 *(5.15)$ \\
$\ln O F V$ & $0.02 * *(2.40)$ & - & $0.02 *(3.08)$ & - \\
$\ln s_{k}$ & $0.12 * *(-1.99)$ & $0.14 * *(-2.05)$ & $0.08 *(-3.12)$ & $0.14 *(-9.41)$ \\
$\ln (n+g+\delta)$ & $-0.31 * *(-2.65)$ & $-0.21 * *(-2.40)$ & $-0.29 *(-4.78)$ & $-0.29 *(-5.12)$ \\
\hline
\end{tabular}

Note: The null hypothesis for the $t$-ratio is $\mathrm{H}_{0}=\beta_{i}=0$; Figures in parentheses are $t$-statistics

$(*)$ and $(* *)$ significant with 95\% (90\%) confidence level; "within-dimension" reports Pedroni (1996) weighted within-dimension adjusted-FM. "between-dimension" reports Pedroni $(1996,2000)$ group mean panel FMOLS.

Table 5 presents the results of within group and panel group FMOLS with time dummies, respectively. In within group, all variables reported that tests rejected the null hypotheses of non- cointegration at the $1 \%$ and $5 \%$ level of significance. On the other hand, panel group showed that all variables reported that tests rejected the null hypotheses of non-cointegration at the $1 \%$ and $5 \%$ levels of significance. Model 1 in within and panel group, the estimated coefficient for the government expenditure on health (ln he) was positive [1.69 (within group) and 1.99 (panel group)] and statistically significant at the $5 \%$ (within group) and 1\% (panel group) levels, while the estimated coefficient for the government expenditure on education (ln ee) was also positive [2.07 (within group) and 0.85 (panel group)] and statistically significant at the $5 \%$ level in within group and statistically significant at the $1 \%$ level in panel group. Therefore, there was a long-run cointegration between education and health expenditures, and economic growth.

For defence expenditure (ln $d e$ ) in Model 1 in both groups, the null hypotheses of non- cointegration was rejected and the coefficient was negative [-0.76 7 (within group) and -4.22 (panel group)] and statistically significant at 5\% level in within group and significant at the $1 \%$ level in panel group. Therefore, there was a long-run cointegration and defence expenditure had an adverse affect on economic growth. The estimated coefficient for the aggregate of other fiscal variables $(\ln O F V)$ in both groups were positive [0.03 (within group) and 0.02 (panel group)] and statistically significant at the $1 \%$ level. The results in both models showed that the aggregate of fiscal policy positively affected growth and there was a long-run cointegration between the aggregate of fiscal policy and economic growth.

The estimated coefficient for the savings in physical capital (investment) ( $\ln s_{k}$ ) was positive (0.13) for Model 1 and statistically significant at the $5 \%$ level in within group. Panel group showed that the estimated coefficient for the savings in physical capital (investment) ( $\ln s_{k}$ ) was positive (0.19) for Model 1 and statistically significant at the $1 \%$ level. These results showed that the investment in within group and panel group have 
a long-run cointegration with economic growth. In within group and panel group, the coefficient on population growth $(\ln (n+g+\delta)$ was negative [0.22 (within group) and -0.24 (panel group)] and statistically significant at the $5 \%$ level in within group and statistically significant at the $1 \%$ level in panel group. We concluded that there was still a long-run cointegration between population growth, and economic growth, and population growth had an adverse effect on economic growth.

Table 5

FMOLS Results, with Time Dummies: Dependent Variable: Real Per Capita GDP

\begin{tabular}{lcccc}
\hline & \multicolumn{2}{c}{ Within Group } & \multicolumn{2}{c}{ Panel Group } \\
& Model 1 & Model 2 & Model 1 & Model 2 \\
\hline $\ln h e$ & $1.69 * *(2.71)$ & - & $1.99 *(3.18)$ & - \\
$\ln e e$ & $2.07 * *(1.82)$ & - & $0.85 *(-3.96)$ & - \\
$\ln d e$ & $-0.76 * *(-2.62)$ & - & $-4.22 *(-7.31)$ & - \\
$\ln d t$ & - & $-0.03 * *(-2.36)$ & - & $-0.79 *(-4.48)$ \\
$\ln b b$ & - & $-0.04 * *(-2.71)$ & - & $-0.06 *(-4.53)$ \\
$\ln G E$ & - & $2.18^{* *}(-3.39)$ & - & $0.04 *(-12.62)$ \\
$\ln O F V$ & $0.03 *(3.43)$ & - & $0.02 *(-4.12)$ & - \\
$\ln s_{k}$ & $0.13 * *(-1.98)$ & $0.14 * *(-2.05)$ & $0.19 *(-4.38)$ & $0.20 *(-8.81)$ \\
$\ln (n+g+\delta)$ & $-0.22 * *(2.65)$ & $-0.21 * *(2.40)$ & $-0.24 *(-4.09)$ & $-0.26 *(-9.23)$ \\
\hline
\end{tabular}

Note: The null hypothesis for the $t$-ratio is $\mathrm{H}_{0}=\beta_{i}=0$; Figures in parentheses are $t$-statistics

(*) and (**) significant with 95\% (90\%) confidence level; "within-dimension" reports Pedroni (1996) weighted within-dimension adjusted-FM. "between-dimension” reports Pedroni $(1996,2000)$ group mean panel FMOLS.

Within group in Model 2, all variables reported that tests rejected the null hypotheses of non- cointegration at the $1 \%$ and $5 \%$ levels. While in panel group, we found that all variables reported tests that rejected the null hypotheses of noncointegration at the $1 \%$ level. Both groups showed that there is a negative coefficient [-0.03 (within group) and -0.79 (panel group)] and statistically significant at the 5\% (within group) and $1 \%$ (panel group) levels for the distortionary taxatin $(\ln d t)$. The estimated coefficient of the budget balance $(\ln b b)$ was also negative [-0.04 (within group) and -0.06 (panel group)] and statistically significant at the $5 \%$ level in within group and statistically significant at the $1 \%$ level in panel group. The results in both groups showed that the distortionary taxation and budget balance have an adverse effect on economic growth, which means that there is a long-run cointegration between the distortionary taxation and budget balance, and economic growth.

In Model 2 we also found that the estimated coefficient for the aggregate of government expenditure (ln $G E$ ) was positive [2.18 (within group) and 0.04 (panel group)] and statistically significant at the $5 \%$ level in within group and statistically significant at the $1 \%$ level in panel group. We concluded that there was a presence of a long-run relationship between GDP and government expenditure. The estimated coefficient for the savings in physical capital (investment) (ln $s_{k}$ ) was positive [0.14 (within group) and 0.20 (panel group)] and statistically significant at the $5 \%$ level in within group and statistically significant at the $1 \%$ level in panel group. Therefore, we concluded that investment and 
economic growth have a long-run cointegration. The coefficient on population growth $(\ln (n+g+\delta)$ was negative (-0.21) and statistically significant at the $5 \%$ level in within group. On the other hand, the coefficient on population growth $(\ln (n+g+\delta)$ was negative $(-0.26)$ and statistically significant at the $1 \%$ level in panel group. These results in both groups showed that there still was long-run cointegration between population growth and economic growth, and population growth had an adverse effect on economic growth.

Comparing the results reported in within group and panel group, we found that the panel groups gave higher values of estimation coefficient and higher values of significance ( $1 \%$ level) which would be a more accurate representation of the average long-run relationship. Therefore, we concluded that all variables were cointegrated and there was long-run relationship. Overall, our results in Table 4 and Table 5 containing the panel estimators' tests showed that the within groups estimator without and with time dummies almost had the coefficient of panel relative all variables levels and were statistically significant at $1 \%$ and $5 \%$ levels. Meanwhile, for the panel groups' estimator without and with time dummies had the coefficient of panel relative all variable levels, and were statistically significant at $1 \%$ level. It was interesting to note that panel groups FMOLS estimators consistently produce larger estimates than do the within groups estimators. Therefore, our results were the same as Pedroni's (2001) arguments that the panel groups estimators produced consistent estimates of the average slope under the alternative hypothesis that the slopes are different from one another and vary across countries, whereas the within groups estimators do not.

\section{CONCLUSION}

The recent models of government expenditure and economic growth developed by Barro (1990) and Devarajan et al. (1996) pointed to the functional composition of government expenditure as a decisive factor. In our study, we focused on three types of government expenditures, namely government expenditure on health, education, and defence. We found that only two types, which were government expenditure on health and education, may well have a large impact on long-run growth as well. Health expenditure for example may well increase life expectancy. Increased life expectancy in turn may have a significant impact on gross capital accumulation decisions and hence on economic growth. Thus, education expenditure and expenditure on health are beneficial for economic growth up to a point and then inhibit growth. On the other hand, our results showed that defence expenditure has a negative and significant effect on economic growth. This is very clear evidence of a military build-up in our selected Asian countries. Defence expenditure must be seen as a long-term investment, not dependent on the ups and downs of the economy from year to year. A credible defence capability is the pre-condition for Asia's is continued peace and prosperity.

We assessed the empirical evidence on the link between the other fiscal variables and economic growth by considering five policy areas: public sector wages and salaries, expenditure on other goods and services, transfers and subsidies, interest payment on government debt, capital expenditure (minus government expenditure on health, education, and defence), tax revenues, nontax revenues, and grants. The analyses of the other fiscal variables in 13 Asian economies showed that the authorities do make active use of fiscal policy. This implied that fiscal policy is practically possible and can be effective in influencing the real per capita GDP. There is thus a rationale for fiscal policy.

We also assessed the empirical evidence on the link between government expenditure and economic growth by considering three expenditure areas: health expenditure, education expenditure, and defence expenditure. The analyses of government expenditure in 13 Asian economies showed that the authorities do make active use of government expenditure even though there are very limited areas. This implied that government expenditure is practically possible and can be effective in influencing the real per capita GDP.

Our studies on distortionary taxation and budget balance matched with several studies influenced by the new growth theories and had 
taken a cross country regression to assess the impact of distortionary taxation and budget balance on real per capita GDP (economic growth) at the macro level. Our analysis through Fully Modified OLS methods demonstrated a significant negative relationship between the level of the distortionary taxation and budget balance, and the growth rate of GDP per capita, implying that distortionary taxation and budget balance reduce economic growth. On the other hand, we found that savings in physical capital (investment) and population growth rate were significantly positive and negative related to GDP per capita, respectively.

\section{REFERENCES}

Abu-Bader, S., \& Abu-Qarm, A.S. (2003). Government expenditure, military spending and economic growth: Causality evidence from Egypt, Israel, and Syria. Journal of Policy Modeling, 25, 567-583.

Al-Awad, M., \& Harb, N. (2005). Financial development and economic growth in the Middle East. Applied Financial Economics 15, 1041-1051.

Barro, R. J., (1990). Government spending in a simple Model of Endogenous Growth. Journal of Political Economics, 98, 103-125

Barro, R.J., \& Sala-I-Martin, X. (1995). Economic growth. McGraw-Hill: New York.

Bleaney, M., Gemmell, N., \& Kneller, R. (2001). Testing the Endogenous Growth Model: Public expenditure, taxation, and growth over the long-run. Canadian Journal of Economics 34 (1), 36-57.

Biswas, B., \& Ram, R. (1986). Military expenditures and economic growth in developing countries: An augmented model and further evidence. Economic Development and Cultural Change, 34, 361-372.
Benos, K. (2005). Fiscal policy and economic growth: Empirical evidence from OECD countries. University of Cyprus, Discussion Paper 2005-01.

Caselli, F., Esquivel, G., \& Lefort, F. (1996). Reopening the convergence debate: A new look at cross-country growth empirics. Journal of Economic Growth, 1, 363389.

Cashin, P. (1995). Government spending, taxes, and economic growth. International Monetary Fund Staff Papers, 42, 237 269.

Chen, P., \& Gupta, R. (2006). An investigation of openness and economic growth using panel estimation. University of Pretoria, Working Paper 2006-22.

Christopoulos, D. K., \& Tsionas, E. G. (2003), Testing the Buchaman-Wagner hypothesis: European evidence from panel unit root and cointegration tests, Public Choice, $115,439-453$.

Christopoulos, D.K., \& Tsionas, E.G. (2004). Financial development and economic growth: Evidence from panel unit root and cointegration tests. Journal of Development Economics, 73, 55-74.

Campbell, J.Y., \& Perron, P. (1991). Pitfalls and opportunities: What macroeconomists should know about unit roots. NBER: Macroeconomics Annual, National Bureau of Economic Research, Cambridge, MA.

Coiteux, M., \& Olivier, S. (2000). The saving retention coefficient in the long run and in the short run: Eviden from panel data. Journal of International Money and Finance, 19, 535-548.

Demetriades, P., \& Law, S.H. (2006). Finance, institutions and economic development. International Journal of Finanace and Economics, 11, 1-16. 
Devarajan, S., Swaroop, V., \& Zou, H. (1996). The composition of public expenditure and economic growth. Journal of Monetary Economics, 37(2), 313-344.

Engen, E., \& Skinner, J. (1993). Fiscal policy and economic growth. Manuscript (University of Virginia, Charlottesville, VA).

Fisher, R. A. (1932). Statistical methods for research workers (12 ${ }^{\text {th }}$ ed.). Edinburgh: Oliver and Boyd.

Fotster, S., \& Henrekson, M. (2001). Growth effects of government expenditure and taxation in rich countries. European Economic Review, 45, 1501-1520.

Gangopadhyay, S., \& Chatterji, A. (2005). Economic globalization in Asia. Ashgate Publishing.

Gbesemete, K.P., \& Gerdtham U.G. (1992). Determinants of health care expenditure in Africa: A cross-sectional study. World Development, 20, 303-308.

Gerson, P. (1998). The impact of fiscal policy variables on output growth. International Monetary Fund. Working Paper 98/1.

Glomm, G., \& Ravikumar, B. (1994). Public investment in infrastructure in a Simple Growth Model. Journal of Economic Dynamics and Control, 18, 1173-1188.

Ghura, D., \& Hadjimichael, M.T. (1996). Growth in Sub-Saharan African. IMF Staff Paper, 43, 605-635.

Hassan, M.K., Waheeduzzaman, M., \& Rahman, A. (2003). Defense expenditure and economic growth in the SAARC countries. The Journal of Social, Political, and Economic Studies, 28(3), 275-293.

Hansson, P., \& Hendrekson, M. (1994). A new framework for testing the effect of government spending on growth and productivity. Public Choice, 31, 381-401.
Hitris, T., \& Posnett, J. (1992). The determinants and effects of health expenditure in developed countries. Journal of Health Economic, 11, 173-181.

Hoeffler, A. K. (2002). The augmented Solow Model and the African growth debate, Oxford Bulletin of Economics and Statistics, 64(2), 0305-9049.

Im, K. S., Pesaran, M. H., \& Shin, Y. (1997). Testing for unit roots in heterogeneous panels. Discussion Paper, University of Cambridge, December.

Islam, N. (1995). Growth empirics: A panel data approach. Quarterly Journal of Economics, $110,1127-1170$.

Kneller, R., Bleaney M. F., \& Kneller, N. (1999). Fiscal policy and growth: Evidence from OECD countries. Journal of Public Economics, 74, 171-190.

Knight, M., Loayza, N., \& Villanueva, D. (1993). Testing the Neoclassical Theory of economic growth, a panel data approach. International Monetary Fund Staff Paper, 40 (3).

Landau, D. (1986). Government and economic growth in less developed countries: An empirical study. Economic Development and Culture Change, 35, 35-75.

Landau, D. (1997). Government expenditure, human capital creation and economic growth. Journal of Public Budgeting, Accounting and Financial Management, 9 (3), 467-487.

Lee, C., \& Chang, C. (2006). Social security expenditures and economic growth: A heterogeneous panel application. Journal of Economic Studies, 33 (5), 386-404.

Levin, A., Lin, C. F., \& Chu, J. (2002). Unit root test in panel data: Asymptotic and finite sample properties. Journal of Econometrics, 108, $1-24$. 
MacDonald, R., \& Nagayasu, J. (2000). The longrun relationship between real exchange rates and real interest rate differentials: A panel study. IMF Staff Paper, 47(1), International Monetary Fund.

McCoskey, S.K., \& Selden, T.M. (1998). Health care ecpenditures and GDP: Panel data unit root test results. Journal of Health Economics, 17, 369-376.

Maddala, G.S., \& Wu, S. (1999). A comparative study of unit root tests with panel data and a new simple test. Oxford Bulletin of Economics and Statistics, 61, 631-652.

Mankiw, G., Romer, D., \& Weil, D. (1992). A contribution to the empirics of economic growth. Quarterly Journal of Economics, 107, 407-437.

Mundle, S. (1999). Fiscal policy and growth some Asian lessons for Asia. Journal of Asian Economics, 10, 15-36.

Oh, K, Kim, B., Kim, H., \& Ahn, B. (1999), Savings-investment cointegration in panel data, Applied Economics Letters, $6,477-472$.

Pedroni, P. (2004). Panel cointegration: Asymptotic and finite samples properties of pooled time series tests with an application to the PPP hypothesis. Econometric Theory, 20, 597-625.

Pedroni, P. (1996). Fully modified OLS for heterogenous cointegrated panels and the case of purchasing power parity. Working paper, North American Econometric Society Summer Meeting.
Pedroni, P. (1999). Critical values for cointegration tests in Heterogeneous Panels with multiple regressors. Oxford Bulletin of Economics and Statistics Special Issue, 61, 653-678.

Pedroni, P. (2001). Purchasing power parity tests in cointegrated panels. The Review of Economics and Statistics, 83(4), 727731.

Pedroni, P. (2000). Fully modified OLS for heterogeneous cointegration panel in nonstationary panels, panel cointegration and dynamic panels. Advances in Econometrics, 15, 93-130.

Phillips, P. C. B., \& Hansen, B. E. (1990). Statistical inference in instrumental variables Regression with I (1) Processes. Review of Economic Studies, 57, 99-125

Ramirez, M.D., \& Nazmi, N. (2003). Public investment and economic growth in Latin America: An empirical test. Review of Development Economics, Blackwell Publishing, 7(1), 115-126.

Yasin, M. (2003). Public spending and economic growth: Empirical investigation of subSaharan Africa. Southwestern Economic Review, 59-68

Tanzi, V., \& Zee, H. (1997). Fiscal policy and long-run growth. International Monetary Fund Staff Papers, 44, 65-94.

Zagler, M., \& Dürnecker, G. (2003). Fiscal policy and economic growth. Journal of Economic Survey, 17(3), 397-418. 